\title{
Fungi colonizing tansy phacelia plants (Phacelia tanacetifolia Benth.) after fungicides treatments
}

\section{Grzyby zasiedlające rośliny facelii błękitnej (Phacelia tanacetifolia Benth.) traktowane fungicydami}

\author{
Sylwia Stępniewska-Jarosz*, Roman Kierzek, Jagoda Wojczyńska, Katarzyna Sadowska, \\ Małgorzata Tyrakowska, Natalia Łukaszewska-Skrzypniak, Maria Rataj-Guranowska
}

\begin{abstract}
Summary
Tansy phacelia (Phacelia tanacetifolia Benth.) is considered a disease-resistant plant. The aim of the study was to determine which fungi (pathogens and saprofites) colonize phacelia plants. The greenhouse and field experiments were conducted in 2016. Phacelia plants were treated with fungicides from different chemical groups. Three combinations of products in the greenhouse experiment and 4 combinations in the field experiment were used. Plants without any protective treatments were used as a control. Parts of plants showing some disease symptoms were selected for isolation of saprotrophic and pathogenic fungi. The isolated and identified fungus species obtained from individual samples differed qualitatively and quantitatively. Among the pathogenic fungi the most important were Fusarium spp. [mainly Fusarium solani (Mart.) Sacc., Fusarium avenaceum (Fr.) Sacc., Fusarium equiseti (Corda) Sacc. and Fusarium oxysporum Schltdl.], Botrytis cinerea Pers., Sclerotinia sclerotiorum (Lib.) de Bary, Alternaria alternata (Fr.) Keissl. and Pythium irregulare Buisman. In some cases large differences in the occurrence of pathogens have been observed, depending on the site of the experiment (field and greenhouse) and on the type of fungicides.
\end{abstract}

Key words: tansy phacelia; fungi; pathogens; saprotrophs; diseases; fungicides

\section{Streszczenie}

Facelia błękitna (Phacelia tanacetifolia Benth.) uważana jest za roślinę odporną na choroby. Celem pracy było sprawdzenie, jakie grzyby (patogeny i saprotrofy) zasiedlają facelię. Doświadczenie w warunkach szklarniowych i polowych przeprowadzono w 2016 roku. Rośliny facelii traktowano nalistnie fungicydami z różnych grup chemicznych. Zastosowano 3 kombinacje preparatów w doświadczeniu szklarniowym i 4 kombinacje $w$ doświadczeniu polowym. Jako kontroli użyto roślin niepoddawanych żadnym zabiegom ochronnym. Do izolacji grzybów wybierano fragmenty roślin z objawami chorobowymi. Zbiorowiska grzybów pozyskane z poszczególnych prób różniły się między sobą jakościowo i ilościowo. Spośród grzybów patogenicznych najbardziej licznie wystąpiły Fusarium spp. [głównie Fusarium solani (Mart.) Sacc., Fusarium avenaceum (Fr.) Sacc., Fusarium equiseti (Corda) Sacc. i Fusarium oxysporum Schltdl.], Botrytis cinerea Pers., Sclerotinia sclerotiorum (Lib.) de Bary, Alternaria alternata (Fr.) Keissl. oraz Pythium irregulare Buisman. W niektórych przypadkach stwierdzono duże różnice w występowaniu patogenów w zależności od miejsca przeprowadzania doświadczenia (pole i szklarnia) i od zastosowanych fungicydów.

Słowa kluczowe: facelia błękitna; grzyby; patogeny; saprotrofy; choroby; fungicydy 


\section{Wstęp / Introduction}

Facelia błękitna, zwana inaczej wiązanką wrotyczową (Phacelia tanacetifolia Benth.), pochodzi z Kalifornii, a do Europy została sprowadzona w pierwszej połowie 19. wieku. Początkowo traktowano ją jako roślinę ozdobną, wysiewaną w ogrodach botanicznych. Obecnie jest bardzo ceniona przede wszystkim jako roślina miododajna (Pruszyński i Mrówczyński 2015). Zapylana jest głównie przez pszczoły, stanowiąc dobre źródło pyłku (Mystkowska i Zarzecka 2012). Ponadto facelię wykorzystuje się jako paszę i nawóz zielony. Jest rośliną jednoroczną, wytrzymałą na przymrozki do $-10^{\circ} \mathrm{C}$ i o niewielkich wymaganiach glebowych, odporną na warunki stresowe ma zdolność kiełkowania przy niewielkiej wilgotności gleby, dobrze toleruje okresy suszy i niski odczyn gleby. Jest także ceniona ze względu na krótki okres wegetacji (około 100 dni) oraz dynamiczny wzrost, dzięki czemu może szybko zacienić glebę i zagłuszać chwasty. Może być uprawiana $\mathrm{w}$ plonie głównym (plon zielonki około 30 t/ha) i jako poplon (plon zielonki 10-20 t/ha), zarówno w siewie czystym, jak i w mieszankach (Pruszyński i Mrówczyński 2015), np. z gorczycą, seradelą i łubinem. Wraz ze wzrostem popularności upraw ekologicznych ze względu na swoje właściwości, wzrosło też zainteresowanie jej wysiewem w międzyplonie ścierniskowym. Produkcja dużej ilości masy zielonej powoduje po przyoraniu poplonu razem $\mathrm{z}$ masą korzeni wniesienie do gleby masy organicznej, która zwiększa plony i poprawia ich jakość (Ramenda 2003).

Szczególnie korzystna jest uprawa facelii w gospodarstwach z uproszczonym zmianowaniem, gdzie swoimi właściwościami niweluje skutki zbyt dużego udziału zbóż w zasiewach. Podaje się, że stosowana w płodozmianie ma m.in. działanie fitosanitarne - ogranicza występowanie w glebie niektórych patogenów. Przydatna jest przede wszystkim $\mathrm{W}$ płodozmianie $\mathrm{z}$ częstą uprawą rzepaku ozimego, gdyż ogranicza występowanie mątwika burakowego (Heterodera schachtii Schmidt), namnażanego intensywnie w obecności kapustnych (Szymczak-Nowak i Nowakowski 2000).

Obecnie w Krajowym Rejestrze (KR) znajduje się 7 odmian facelii błękitnej: Anabela, Angelia, Asta, Atara, Lisette, Natra, Stala. Odmiana Natra, wyhodowana w Polsce, daje wysoki plon masy zielonej - do 100 t/ha. Ogranicza liczebność mątwika burakowego o 29,3\% w porównaniu do czarnego ugoru (Ramenda 2003).

Przyjmuje się, że facelia nie jest podatna na wiele chorób. W Polsce nie ma obecnie fungicydów (zarówno w formie zapraw, jak i środków nalistnych) zarejestrowanych w uprawie tej rośliny. Ze względu na szereg zalet i cech użytkowych cieszy się coraz większą popularnością i można spodziewać się, pojawienia pierwszych chorób.

Celem pracy było sprawdzenie podatności roślin facelii błękitnej na porażenie przez sprawców chorób grzybowych. Zbadano, jakie grzyby (saprotrofy i patogeny) zasiedlają rośliny zarówno w warunkach szklarniowych, jak i polowych, również po zastosowaniu fungicydów zawierających różne substancje czynne. Porównano zbiorowiska grzybów pochodzące $\mathrm{z}$ facelii $\mathrm{z}$ doświadczenia szklarniowego i polowego. Ponadto sprawdzono, które substancje czynne mogłyby być skuteczne w ochronie facelii przed grzybami - sprawcami chorób facelii.

\section{Materiały i metody / Materials and methods}

Doświadczenie szklarniowe i polowe w Winnej Górze (Polowa Stacja Doświadczalna Instytutu Ochrony Roślin Państwowego Instytutu Badawczego; wschodnia część powiatu i gminy Środa Wielkopolska) przeprowadzono w 2016 roku. Rośliny facelii odmiany Natra przed kwitnieniem traktowano nalistnie stosowanymi powszechnie $\mathrm{w}$ uprawie innych roślin fungicydami $\mathrm{z}$ różnych grup chemicznych. Zastosowano 3 kombinacje preparatów w doświadczeniu szklarniowym (tab. 1) i 4 kombinacje w doświadczeniu polowym (tab. 2). Jako kontroli użyto roślin facelii niepoddawanych żadnym zabiegom ochronnym.

Do izolacji grzybów wybierano porażone fragmenty roślin, które dezynfekowano powierzchniowo przez 30 sekund w 5\% roztworze podchlorynu sodu (ACE). Następnie próby płukano w wodzie destylowanej, suszono i wykładano na płytki Petriego z pożywką PDA (Potato Dextrose Agar). Izolacje wykonano łącznie na 100 płytkach w doświadczeniu szklarniowym i 125 płytkach w doświadczeniu polowym, po 25 płytek na każdą kombinację. Na jednej płytce znalazły się fragmenty 1 rośliny z objawami chorobowymi (korzenia i łodygi). Inkubację prowadzono $\mathrm{w}$ termostacie przy stałej temperaturze $24^{\circ} \mathrm{C}$. Wyrastające kolonie grzybów przeszczepiano na pożywkę syntetyczną PDA. Wyrosłe po kilku dniach kolonie grzybów przeszczepiono i poddano analizie makroskopowej (wygląd kolonii) oraz mikroskopowej (wytwarzanie zarodników i innych charakterystycznych struktur). Następnie przeszczepiano je na pożywki pomocne przy identyfikacji - SNA (Synthetic Nutrient Poor Agar), V8 (pożywka wielowarzywna) i PCA (Potato Carrot Agar). Grzyby zidentyfikowano na podstawie kluczy i monografii (Booth 1971; Domsch i wsp. 1980; Sutton 1980; van der Plaats-Niterink 1981; Burgees i wsp. 1988; Kwaśna i wsp. 1991; Ellis 2001) w 2016 i 2017 roku.

\section{Wyniki i dyskusja / Results and discussion}

$\mathrm{Na}$ pobranych próbach roślin nie zaobserwowano objawów rdzy, mączniaka prawdziwego i rzekomego facelii. $\mathrm{W}$ doświadczeniu szklarniowym w wyniku izolacji $\mathrm{z}$ roślin $\mathrm{z}$ innymi objawami chorobowymi pozyskano 426 izolatów, a w doświadczeniu polowym 732 izolaty grzybów. Zbiorowiska grzybów z poszczególnych prób różniły się między sobą jakościowo i ilościowo (tab. 1, 2). W obu doświadczeniach najbardziej zasiedlone przez grzyby (saprotrofy i patogeny) okazały się rośliny zebrane z obiektów kontrolnych. Grzyby wyosobnione z roślin $\mathrm{z}$ tych obiektów były też najbardziej urozmaicone gatunkowo. W obu doświadczeniach zarówno w kombinacjach z fungicydami, jak i na obiektach kontrolnych, wystąpiły grzyby będące saprotrofami, jak i patogeny roślin. Saprotrofy najliczniej reprezentowane były w doświadczeniu polowym i szklarniowym na obiektach kontrolnych. 
Wyniki niniejszych badań odbiegają od opinii, że na plantacjach w warunkach sprzyjających rozwojowi patogenów można zaobserwować jedynie objawy zgorzeli siewek, szarej pleśni, rdzy facelii oraz mączniaka - rzekomego i prawdziwego (Pruszyński i Mrówczyński 2015). Rok 2016, w którym przeprowadzano doświadczenie, był rokiem wilgotnym i ciepłym (Główny Urząd Statystyczny 2016, 2017), co też zapewne sprzyjało wystąpieniu chorób roślin. Roczna suma opadów atmosferycznych w 2016 ro$\mathrm{ku}$ wyniosła $608 \mathrm{~mm}$ (w latach 2001-2010 było to $535 \mathrm{~mm}$, a w latach 2013-2015 odpowiednio 594, 558 i $438 \mathrm{~mm})$, natomiast średnia temperatura powietrza $9,8^{\circ} \mathrm{C}\left(9,2^{\circ} \mathrm{C}\right.$ w latach $2001-2010, \mathrm{w}$ roku $2013-9,2^{\circ} \mathrm{C}$, w $2014-10,5^{\circ} \mathrm{C}$, a w $\left.2015-10,4^{\circ} \mathrm{C}\right)$.

Spośród grzybów patogenicznych na wszystkich obiektach w doświadczeniu szklarniowym najbardziej licznie wystąpił Botrytis cinerea Pers., grzyby rodzaju
Fusarium [głównie Fusarium solani (Mart.) Sacc., Fusarium avenaceum (Fr.) Sacc. i Fusarium equiseti (Corda) Sacc.] oraz Alternaria alternata (Fr.) Keissl. Z kolei w warunkach polowych, oprócz wyżej wymienionych grzybów, licznie notowany był gatunek Fusarium oxysporum Schltdl. Na zebranych z doświadczenia roślinach wyraźnie odznaczały się różowe plamy, widoczne zwłaszcza na łodygach. Grzyby rodzaju Fusarium są odpowiedzialne za powodowanie wielu chorób roślin, m.in. fuzaryjnej zgorzeli podstawy źdźbła i korzeni, zgorzeli siewek, fuzariozy kłosów i wiech. Nie tylko obniżają plon roślin, ale także zanieczyszczają zbiory groźnymi mykotoksynami (Chełkowski 1985; Wolny-Koładka 2014). Mają zdolność porażania roślin we wszystkich fazach rozwojowych. Na polu mogą pozostawać po zakończeniu okresu wegetacyjnego na resztkach pożniwnych i innych pozostałościach roślin uprawnych (Kaniuczak i Lisowicz 2000).

Tabela 1. Grzyby pozyskane z roślin facelii pochodzących z doświadczenia szklarniowego w zależności od zastosowanej ochrony chemicznej (liczba izolatów)

Table 1. Fungi obtained from phacelia plants originated from the greenhouse experiment depending on chemical protection (number of isolates)

\begin{tabular}{|c|c|c|c|c|}
\hline $\begin{array}{c}\text { Grzyby } \\
\text { Fungi }\end{array}$ & $\begin{array}{c}\text { Kontrola } \\
\text { (bez ochrony) } \\
\text { Control } \\
\text { (without protection) }\end{array}$ & $\begin{array}{c}\text { Amistar 250 EC } \\
\text { (azoxystrobin) } \\
\text { 1,0 l/ha } \\
+ \\
\text { Topsin M } 500 \text { SC } \\
\text { (thiophanate-methyl) } \\
\text { 1,2 l/ha }\end{array}$ & $\begin{array}{c}\text { Amistar 250 EC } \\
\text { (azoxystrobin) } \\
0,75 \mathrm{l} / \mathrm{ha} \\
+ \\
\text { Topsin M } 500 \mathrm{SC} \\
\text { (thiophanate-methyl) } \\
1,2 \mathrm{l} / \mathrm{ha} \\
+ \\
\text { Horizon } 250 \mathrm{EW} \\
\text { (tebuconazole) } \\
0,75 \mathrm{l} / \mathrm{ha}\end{array}$ & $\begin{array}{c}\text { Topsin M } 500 \text { SC } \\
\text { (thiophanate-methyl) } \\
1,2 \text { l/ha }\end{array}$ \\
\hline Alternaria alternata & 12 & 8 & 6 & 11 \\
\hline Aspergillus sp. & 2 & - & - & - \\
\hline Botrytis cinerea & 41 & 7 & 15 & 28 \\
\hline Colletotrichum sp. & 6 & 2 & 5 & 2 \\
\hline Epicoccum purpurescens & 9 & 2 & 7 & 6 \\
\hline Fusarium avenaceum & 13 & 8 & 11 & 8 \\
\hline Fusarium culmorum & 4 & 1 & - & 2 \\
\hline Fusarium equiseti & 8 & 5 & 7 & 5 \\
\hline Fusarium oxysporum & 7 & 1 & 2 & 4 \\
\hline Fusarium solani & 14 & 7 & 5 & 9 \\
\hline $\begin{array}{l}\text { Fusarium spp. } \\
\text { Inne - Others }\end{array}$ & 6 & 1 & - & 4 \\
\hline Mucor hiemalis & 6 & 1 & 3 & 2 \\
\hline Penicillium spp. & 3 & - & - & 1 \\
\hline Phoma spp. & 9 & 4 & 8 & 5 \\
\hline Rhizopus sp. & 4 & - & - & 1 \\
\hline Pythium irregulare & 2 & 1 & 2 & 2 \\
\hline Rhizoctonia solani & 2 & - & - & - \\
\hline Sclerotinia sclerotiorum & 11 & 5 & - & - \\
\hline Trichoderma sp. & 6 & - & - & - \\
\hline Ulocladium atrum & 2 & - & - & 4 \\
\hline Inne - Others & 10 & 11 & 3 & 8 \\
\hline Suma - Sum & 177 & 73 & 74 & 102 \\
\hline
\end{tabular}


Tabela 2. Grzyby pozyskane z roślin facelii pochodzących z doświadczenia polowego w zależności od zastosowanej ochrony chemicznej (liczba izolatów)

Table 2. Fungi obtained from phacelia plants originated from the field experiment depending on chemical protection (number of isolates)

\begin{tabular}{|c|c|c|c|c|c|}
\hline $\begin{array}{l}\text { Grzyby } \\
\text { Fungi }\end{array}$ & $\begin{array}{c}\text { Kontrola } \\
\text { (bez ochrony) } \\
\text { Control } \\
\text { (without } \\
\text { protection) }\end{array}$ & $\begin{array}{c}\text { Horizon } 250 \mathrm{EW} \\
\text { (tebuconazole) } \\
1,0 \mathrm{l} / \mathrm{ha}\end{array}$ & $\begin{array}{c}\text { Amistar } 250 \text { EC } \\
\text { (azoxystrobin) } \\
\text { 1,0 l/ha } \\
+ \\
\text { Topsin M } 500 \text { SC } \\
\text { (thiophanate-methyl) } \\
\text { 1,2 l/ha }\end{array}$ & $\begin{array}{c}\text { Amistar 250 EC } \\
\text { (azoxystrobin) } \\
0,75 \text { l/ha } \\
+ \\
\text { Topsin M } 500 \mathrm{SC} \\
\text { (thiophanate-methyl) } \\
1,2 \mathrm{l} / \mathrm{ha} \\
+ \\
\text { Horizon } 250 \mathrm{EW} \\
\text { (tebuconazole) } \\
\text { 0,75 l/ha }\end{array}$ & $\begin{array}{c}\text { Topsin M } 500 \text { SC } \\
\text { (thiophanate-methyl) } \\
\text { 1,2 l/ha }\end{array}$ \\
\hline Alternaria alternata & 10 & 8 & 8 & 2 & 11 \\
\hline Aspergillus sp. & 8 & 3 & - & - & 2 \\
\hline Botrytis cinerea & 68 & 41 & 37 & 27 & 28 \\
\hline $\begin{array}{l}\text { Cladosporium } \\
\text { cladosporioides }\end{array}$ & 6 & 2 & - & - & 1 \\
\hline Colletotrichum sp. & 4 & 2 & - & - & - \\
\hline Epicoccum purpurescens & 26 & 3 & 1 & - & 2 \\
\hline Fusarium avenaceum & 13 & 18 & 11 & 8 & 14 \\
\hline Fusarium culmorum & 2 & - & - & 2 & 1 \\
\hline Fusarium equiseti & 7 & 8 & 11 & 9 & 12 \\
\hline Fusarium oxysporum & 11 & 6 & 5 & 5 & 4 \\
\hline Fusarium solani & 2 & - & 4 & 3 & 4 \\
\hline $\begin{array}{l}\text { Fusarium spp. } \\
\text { Inne - Others }\end{array}$ & 7 & 3 & 2 & 6 & 1 \\
\hline Mucor hiemalis & 21 & 4 & 1 & 3 & 2 \\
\hline Penicillium spp. & 9 & 2 & - & - & - \\
\hline Phoma spp. & 4 & 5 & 4 & 8 & 11 \\
\hline Rhizopus sp. & 4 & 1 & - & - & 1 \\
\hline Pythium irregulare & 13 & 2 & - & 11 & - \\
\hline Rhizoctonia solani & 3 & - & 4 & 2 & - \\
\hline Sclerotinia sclerotiorum & 18 & 2 & 38 & 7 & - \\
\hline Trichoderma sp. & 10 & 1 & - & - & 2 \\
\hline Ulocladium atrum & 18 & 3 & 1 & - & 3 \\
\hline Inne - Others & 10 & 8 & 4 & 4 & 9 \\
\hline Suma - Sum & 275 & 122 & 131 & 97 & 107 \\
\hline
\end{tabular}

Żadna z zastosowanych kombinacji nie zahamowała całkowicie rozwoju grzybów rodzaju Fusarium. Stopień ograniczenia występowania zależał od gatunku Fusarium (tab. 1, 2). Przykładowo w doświadczeniu polowym F. oxysporum po zastosowaniu tebukonazolu został ograniczony o 46\%, po zastosowaniu mieszaniny azoksystrobiny i tiofanatu metylowego oraz mieszaniny azoksystrobiny, tiofanatu metylowego i tebukonazolu - o 55\%, a po zastosowaniu fungicydu na bazie tiofanatu metylowego - o 64\% w stosunku do kontroli. W doświadczeniu szklarniowym zastosowanie mieszaniny azoksystrobiny i tiofanatu metylowego ograniczyło występowanie tego patogena aż o $86 \%$ (o $71 \%$ po zastosowaniu mieszaniny azoksystrobiny, tiofanatu metylowego i tebukonazolu oraz o $43 \%$ po zastosowaniu tiofanatu metylowego). Zarówno fungi- cydy na bazie azoksystrobiny, jak i tiofanatu metylowego, stosowane powszechnie $\mathrm{w}$ ochronie roślin m.in. przed fuzariozą, słabo ograniczały występowanie tej choroby na roślinach facelii. Skuteczność w ograniczaniu występowania wszystkich grzybów rodzaju Fusarium wyniosła w doświadczeniu polowym od $14 \%$ (po zastosowaniu tiofanatu metylowego), poprzez 17\% (po zastosowaniu tebukonazolu), do 21\% (po zastosowaniu mieszaniny azoksystrobiny i tiofanatu metylowego oraz mieszaniny azoksystrobiny, tiofanatu metylowego i tebukonazolu). W doświadczeniu szklarniowym zastosowane fungicydy w większym stopniu ograniczyły występowanie Fusarium spp., w porównaniu z doświadczeniem polowym (o 39\% po zastosowaniu tiofanatu metylowego, $52 \%$ - po zastosowaniu mieszaniny azoksystrobiny, tiofanatu metylowego 
i tebukonazolu i o $56 \%$ - po zastosowaniu mieszaniny azoksystrobiny i tiofanatu metylowego w stosunku do kombinacji kontrolnej). Ochrona przed grzybami rodzaju Fusarium nie jest łatwa ze względu na brak odmian roślin odpornych. Poza tym trudno dobrać termin zabiegu ochronnego, ponieważ rośliny mogą zostać porażone w każdym stadium rozwoju. Do tego dochodzi duża zmienność gatunkowa w obrębie rodzaju, dotycząca tolerancji na substancje czynne fungicydów. Przykładowo, pomimo zastosowania 10 różnych substancji czynnych w ochronie pszenicy przed fuzariozą kłosów, nie udało się zwiększyć plonów i zahamować rozwoju choroby (Milus i Parsons 1994).

$\mathrm{Na}$ szczególną uwagę zasługuje zaobserwowanie na facelii błękitnej Sclerotinia sclerotiorum (Lib.) de Bary. Patogena tego obserwowano na roślinach $\mathrm{z}$ kombinacji kontrolnej zarówno w doświadczeniu polowym, jak i szklarniowym, a także na niektórych kombinacjach doświadczalnych po zastosowaniu fungicydów. W doświadczeniu polowym tiofanat metylowy okazał się w 100\% skuteczny w ograniczeniu występowania S. sclerotiorum. Zastosowanie tebukonazolu ograniczyło występowanie patogena o 75\%, natomiast mieszaniny azoksystrobiny, tiofanatu metylowego i tebukonazolu - o 61\% w stosunku do obiektu kontrolnego. W kombinacji, gdzie zastosowano mieszaninę fungicydów na bazie azoksystrobiny i tiofanatu metylowego wyosobniono aż 38 izolatów S. sclerotiorum, podczas gdy w kontroli było ich 18. Wynik ten jest zastanawiający i $\mathrm{z}$ całą pewnością badania należałoby powtórzyć w kolejnych latach, zwłaszcza, że w warunkach szklarniowych po zastosowaniu tej samej mieszaniny fungicydów występowanie patogena zostało ograniczone o 55\% w stosunku do kontroli. W doświadczeniu szklarniowym pozostałe dwie zastosowane kombinacje (mieszanina azoksystrobina + tiofanat metylowy + tebukonazol oraz tiofanat metylowy) całkowicie wyeliminowały występowanie $S$. sclerotiorum.

S. sclerotiorum to znany sprawca zgnilizny twardzikowej, nie notowany nigdy wcześniej na facelii błękitnej. $\mathrm{Na}$ tej roślinie znaleziono w Kalifornii jedynie innego, należącego do tego samego rodzaju patogena - Sclerotinia minor Jagger (Koike i wsp. 1996). S. sclerotiorum uważany jest za jednego z najbardziej niespecyficznych i polifagicznych grzybów. Podaje się, że poraża ponad 400 gatunków roślin, głównie dwuliściennych (Bolton i wsp. 2006). Lista ta ciągle się powiększa. W Polsce występuje na buraku, fasoli, marchwi, ogórku, pietruszce, pomidorze, rzepaku, słoneczniku, soi, tytoniu i innych roślinach warzywnych (Kryczyński 2002). Wiadomo też, że w ostatnich latach pojawił się m.in. na lniance siewnej.

Całkowite ograniczenie porażenia roślin facelii przez S. sclerotiorum uzyskano po zastosowaniu fungicydu opartego na tiofanacie metylowym oraz mieszaniny azoksystrobiny z tiofanatem metylowym i tebukonazolem. Substancje czynne, takie jak tebukonazol oraz tiofanat metylowy, skuteczne w przypadku facelii, stosuje się $\mathrm{z}$ powodzeniem do ochrony innych roślin przed czernią krzyżowych.

Ponadto dużym zagrożeniem dla facelii okazał się B. cinerea, sprawca szarej pleśni. W zależności od kombinacji wyosobniono od 7 do 68 izolatów w poszczególnych kombinacjach, najwięcej w kontrolach. Stopień porażenia przez tego patogena zależał od zastosowanego fungicydu. Ogólnie ani tebukonazol, ani tiofanat metylowy (nawet w mieszaninie), zarejestrowane m.in. do ochrony przed szarą pleśnią, nie wyeliminowały całkowicie rozwoju choroby na facelii. Skuteczność zastosowanych fungicydów w ograniczaniu szarej pleśni wyniosła od 40\% dla tebukonazolu, poprzez $46 \%$ dla mieszaniny azoksystrobiny i tiofanatu metylowego, 59\% dla mieszaniny azoksystrobiny z tiofanatem metylowym i tebukonazolem, do 60\% dla tiofanatu metylowego w stosunku do kontroli. Objawy szarej pleśni już wcześniej obserwowano na facelii (Pruszyński i Mrówczyński 2015). B. cinerea powoduje poważne straty na ponad 200 gatunkach upraw na całym świecie. Ten kosmopolityczny grzyb poraża kwiaty, liście, łodygi, owoce i inne części roślin, m.in. tak ważnych ekonomicznie gatunków, jak fasola, sałata, agrest, pomidory i winorośl (Ellis 2001). Jest wyjątkowo trudny do kontrolowania, ponieważ istnieje wiele sposobów jego atakowania, różnorodne rośliny są źródłem inokulum i może przetrwać jako grzybnia i/lub konidia albo też przez dłuższy czas jako sklerocja w odpadach roślinnych. $\mathrm{Z}$ tych powodów jeden zabieg nie wystarczy do zwalczenia patogena (Williamson i wsp. 2007).

Występujący na każdym obiekcie doświadczalnym kosmopolityczny gatunek $A$. alternata to saprotrof/fakultatywny patogen izolowany $\mathrm{z}$ wielu roślin, a znajdowany także m.in. na gnijących resztkach organicznych $w$ glebie (Yu 1992). Przypuszczalnie jest najbardziej rozpowszechnionym gatunkiem grzyba na świecie, zarówno w klimacie umiarkowanym, jak i tropikalnym (Scheffer 1992). Wymienianych jest ponad 80 rodzajów i gatunków roślin, na których może bytować jako słaby patogen lub saprotrof. Może być istotnym patogenem 38 gatunków roślin (Kwaśna 1992). Jak okazało się w niniejszych badaniach, występuje dość licznie również na roślinach facelii.

$\mathrm{Na}$ roślinach facelii $\mathrm{w}$ obu doświadczeniach stwierdzono obecność także innych grzybów patogenicznych, takich jak Phoma spp., Colletotrichum sp. i Rhizoctonia solani. W doświadczeniu polowym na obiekcie kontrolnym i w kombinacjach, gdzie zastosowano sam tebukonazol oraz mieszaninę azoksystrobiny, tiofanatu metylowego i tebukonazolu wystąpiło ponadto Pythium irregulare Buisman. Grzyb ten izolowany był sporadycznie z korzeni facelii na wszystkich obiektach doświadczenia szklarniowego. Jest powszechnym odglebowym patogenem, identyfikowanym na ponad 200 gatunkach roślin (van der Plaats-Niterink 1981; Farr i wsp. 2004). Występuje m.in. na zbożach, trawach, truskawce, soi, soczewicy, kukurydzy, ogórku, selerze, cebuli i marchwi. $P$. irregulare preferuje warunki wysokiej wilgotności dla kolonizacji korzeni i jest powszechnie obecny w szklarniach (Hendrix i Campbell 1973). Tak jak większość gatunków rodzaju Pythium, może powodować przed- i powschodowa zgorzel siewek oraz zgnilizny korzeni starszych roślin (Hendrix i Campbell 1973; Koike i wsp. 2007).

W literaturze podaje się, że facelia jest odporna na choroby. Autorzy tłumaczą to tym, że należy do jedynego gatunku rodziny faceliowatych (Hydrophyllaceae R. Br. in Ker. Gawl) wykorzystywanego rolniczo. Stąd ze względu 
na brak pokrewieństwa $\mathrm{z}$ innymi gatunkami uprawnymi, nie atakują jej choroby czy szkodniki (Mystkowska i Zarzecka 2012). Niniejsze badania nie potwierdzają tej opinii.

\section{Wnioski / Conclusions}

1. Największą różnorodność grzybów (saprotrofów i patogenów) w doświadczeniu polowym i szklarniowym zanotowano na obiektach kontrolnych.

2. Najważniejszymi patogenami - sprawcami chorób facelii w doświadczeniu polowym okazały się: $B$. cinerea, S. sclerotiorum oraz Fusarium spp.
3. Największym zagrożeniem dla roślin facelii w doświadczeniu szklarniowym były grzyby rodzaju Fusarium oraz B. cinerea.

4. Zastosowane fungicydy w różnym stopniu ograniczały występowanie grzybów patogenicznych.

5. Najlepsze działanie grzybobójcze względem S. sclerotiorum uzyskano w doświadczeniu polowym i szklarniowym po zastosowaniu tiofanatu metylowego, a w doświadczeniu szklarniowym także po zastosowaniu mieszaniny azoksystrobiny $\mathrm{z}$ tiofanatem metylowym i tebukonazolem.

\section{Literatura / References}

Bolton M.D., Thomma B.P.H.J., Nelson B.D. 2006. Sclerotinia sclerotiorum (Lib.) de Bary: biology and molecular traits of a cosmopolitan pathogen. Molecular Plant Pathology 7 (1): 1-16. DOI: 10.1111/j.1364-3703.2005.00316.x.

Booth C. 1971. The genus Fusarium. Commonwealth Mycological Institute, Kew, Surrey: 91-97, 237 pp.

Burgees L.W., Liddel C.M., Summerell B.A. 1988. Laboratory Manual for Fusarium Research. Fusarium Research Laboratory, Department of Plant Pathology and Agricultural Entomology, The University of Sydney: 140-141.

Chełkowski J. 1985. Mikotoksyny, wytwarzające je grzyby i mikotoksykozy. Wydawnictwo SGGW-AR, Warszawa, 96 ss.

Domsch W., Gams W., Anderson T.H. 1980. Compendium of Soil Fungi. Vol. 1. Academic Press, London, 859 pp.

Ellis M.B. 2001. Dematiaceous Hyphomycetes. CABI, Wallingford, 608 pp.

Farr D.F., Rossman A.Y., Palm M.E., McCray E.B. 2004. Online. Fungal Databases, Systematic Botany \& Mycology Laboratory. United States Department of Agriculture, Agricultural Research Service.

Główny Urząd Statystyczny 2016. Roczniki Branżowe. Rocznik Statystyczny Rolnictwa. Warszawa, 460 ss.

Główny Urząd Statystyczny 2017. Mały Rocznik Statystyczny Polski 2017. Warszawa, 539 ss.

Hendrix F.F., Campbell W.A. 1973. Pythiums as plant pathogens. Annual Review Phytopathology 11: 77-98.

Kaniuczak Z., Lisowicz F. 2000. Wpływ chemicznej ochrony pszenicy przed chorobami na jakość ziarna i zawartość mikotoksyny. Ochrona Roślin 9: 25-26.

Koike S.T., Gladders P., Paulus A.O. 2007. Vegetable Diseases: A Color Handbook. Academic Press. Boston, MA: 87-88, 226-228, 370-371.

Koike S.T., Smith R.F., Jackson L.E., Wyland L.J., Inman J.I., Chaney W.E. 1996. Phacelia, lana woollypod and Australian winter pea: three new cover crop hosts of Sclerotinia minor in California. Plant Disease 80: 1409-1412.

Kryczyński S. 2002. Choroby roślin w uprawach rolniczych. Wydawnictwo SGGW, Warszawa, 164 ss.

Kwaśna H. 1992. Ecology and Nomenclature of Alternaria. p. 63-100. In: ”Alternaria - Biology, Plant Diseases and Metabolites” (J. Chełkowski, A. Visconti, eds.). Elsevier Science Publishers, Amsterdam.

Kwaśna H., Chełkowski J., Zajkowski P. 1991. Flora Polska T. XXII. Grzyby niedoskonałe. Strzępczakowe. Gruzełkowate. Sierpik (Fusarium). PAN, Warszawa-Kraków, 158 ss.

Milus E.A., Parsons C.E. 1994. Evaluation on foliar fungicides for controlling Fusarium head blight of wheat. Plant Disease 78: 697-699.

Mystkowska I., Zarzecka K. 2012. Facelia błękitna wielostronnie wykorzystywana. Poradnik Gospodarski 5, s. 18.

Pruszyński G., Mrówczyński M. (red.). 2015. Metodyka integrowanej ochrony facelii błękitnej dla producentów. Instytut Ochrony Roślin - Państwowy Instytut Badawczy, Poznań, 25 ss

Ramenda S. 2003. Facelia błękitna. Agrochemia 6: 25-28.

Scheffer R.P. 1992. Ecological and evolutionary roles of toxins from Alternaria species pathogenic to plants. p. 101-122. In: ”Alternaria - Biology, Plant Diseases and Metabolites" (J. Chełkowski, A. Visconti, eds.). Elsevier Science Publishers, Amsterdam.

Sutton B.C. 1980. The Coelomycetes. Fungi imperfecti with picnidia, acervuli and stromata. Commonwealth Mycological Institute, Kew, Surrey, 696 pp.

Szymczak-Nowak J., Nowakowski M. 2000. Efekt antymątwikowy i plonowanie gorczycy białej, facelii błękitnej i rzodkwi oleistej uprawianych w plonie głównym. Rośliny Oleiste 21: 285-291.

van der Plaats-Niterink A.J. 1981. Monograph of the genus Pythium. Studies in Mycology 21. Centraalbureau voor Schimmelcultures, Baarn, 244 pp.

Williamson B., Tudzynski B., Tudzynski P., van Kan L. 2007. Botrytis cinerea: the cause of grey mould disease. Molecular Plant Pathology 8 (5): 561-580. DOI: 10.1111/j.1364-3703.2007.00417.x.

Wolny-Koładka K. 2014. Grzyby z rodzaju Fusarium - występowanie, charakterystyka i znaczenie w środowisku. Kosmos 63 (4): $623-633$.

Yu S.H. 1992. Occurrence of Alternaria species in countries of the far east and their taxonomy. p. 37-62. In: ”Alternaria - Biology, Plant Diseases and Metabolites" (J. Chełkowski, A. Visconti, eds.). Elsevier Science Publishers, Amsterdam. 